\title{
A Second Exodus: Ethiopian Jews in Israel Between Religion, Nation and State
}

\author{
Marva Shalev Marom \\ Stanford University
}

\begin{abstract}
Questions about Jewishness, Judaism, and the Jewish people have been topics of millennia-long debates. In this paper, I focus on the formation of social hierarchies in Israel based on skin-color to argue that there is unresolved yet consequential tension between definitions of Jewishness as a religious tradition, a national identity, and a state apparatus. I embrace the perspective of Ethiopian Jews, whose identities were reframed in Israel as Blacks, to illustrate how this tension placed dark-skinned immigrants beyond the scope of both Jewish religious tradition as well as national identity, to become the marginalized inhabitants of the Jewish State. Thereby I describe and examine two state-imposed processes in which Israel's Rabbinate plays a central role: 1) Israel's demand that Ethiopian Jews convert to Judaism in order to be accorded citizenship. 2) Israel's demand that Ethiopian Jewish children attend a segregated Jewish Orthodox public-school system, to acquire and cultivate a particular national identity. State-sponsored schools have become the basis for both religious and national identity education and re-education.
\end{abstract}

Key words: Jewish nationalism; immigration; religious (re-)education; Skin Color; Zionism.

\section{From Ethiopia to Yerusalem}

Ten years ago, Yerus (pseudoname) immigrated with her Jewish family from Ethiopia to Israel. She shared their Aliyah (immigration) journey with me. That journey had started on her mother's back, on a 700-kilometer route from Walaka, their village in the Amhara Region of Ethiopia, to the Israeli embassy in Addis Ababa, Ethiopia. Yerus, then five years old, didn't know how long or to where they 
walked. She knew but one thing: "Yerusalem." That's where they were heading. After two thousand years, they were finally going home.

At the embassy, thousands of men, women, young and old, children of all ages in traditional garments prayed with dreamful eyes. Later, a few uniformed farangis (white persons) led them to a plane where they were huddled together and continued praying as one. Upon deplaning in Ben Gurion Airport Tel Aviv, her father kneeled to kiss the ground. A farangi approached them. "Shalom," he said, "Welcome to Israel. We are from the Ministry of Aliyah and Integration, and will guide you through the process of becoming an Israeli citizen. Please get on the bus." After a short drive, they arrived at two buildings behind a solid fence. It was the "Absorption Center," a temporary shelter. Here, over the next six months, they were to receive food, vaccines - and lessons in Jewish religion.

During their stay at this Center, many officials explained the Israeli path to citizenship. One brought a list of subsidized housing options; another came with applications to an Ulpan, a tuition-free Hebrew teaching facility for immigrants; a third brought a list of potential employers; a fourth, two schooling options to choose from. The fifth official gave them all Hebrew names: Yerus, which in Amharic means Jerusalem, became Yael, a popular girl's name in Israel. The sixth wore a big black hat and asked to speak to her father.

"We're here to guide you through the conversion process so you could apply for citizenship."

"Conversion?!" Her father opened his eyes wide. "Conversion to what?!"

"To Judaism," said the official.

"But we are Jewish!" he cried, "We walked 700 kilometers to return to Yerusalem!"

"You don't meet the criteria," the official said matter-of-factly. "The Rabbinate will explain the rest."

"Who?!” Yerus remembers asking. Nobody answered.

Gradually, year after year, things got worse. The first school on the list provided by the officials didn't even consider her application. The school Yerus ended up attending was a boarding school where she had to take special Judaism classes, and she was required to teach what she had learned at this school to her parents when returning home on the weekends. During one of these weekends in 2019, a policeman shot and killed her downstairs neighbour, a teenager of Ethiopian decent. Shocked and enraged, Yerus joined ten-thousand community members at a protest in Tel Aviv. The protesters blocked roads and carried signs, "Black=Second Class Citizen," "Police murders Ethiopian Jews." Drivers got out of their cars and yelled at her and others like her: "Go back to Africa." She choked when she remembered how her mother carried her from Africa to get here. Then, she was Yerus, not Yael, and Yerusalem was not yet Israel (Yerus\#18, 2019). 


\section{Research interest and method}

Questions about Jewishness, Judaism, and the Jewish people have been topics of millennia-long debates. Defined and redefined by religious and political leaders, scholars and philosophers, as religion and nationality, society and culture, they also remain ever open. In this paper, I focus on the formation of social hierarchies in Israel based on skin-color to argue that there is unresolved yet consequential tension between definitions of Jewishness as a religious tradition, a national identity, and a state apparatus. I embrace the perspective of Ethiopian Jews, whose identities were authoritatively reframed as Blacks, to illustrate how this tension placed dark-skinned immigrants beyond the scope of both Jewish religious tradition as well as national identity, to become marginalized inhabitants of the Jewish State.

To support this claim, I describe and examine two state-imposed processes:

1. Conversion as a condition for citizenship: Israel demands that Ethiopian Jews convert to Judaism in order to be accorded citizenship. Thus, a religious process is required to gain citizenship, shifting Jewishness from a religious to citizenship status.

2. Jewish education as pathway to nationhood: The state of Israel demands that Ethiopian Jewish children attend a segregated Jewish Orthodox public-school system to acquire and cultivate a national identity. State-sponsored schools have become the basis for both religious and national identity education and re-education.

Gathering evidence to support this argument was a community enterprise. I worked as a Hebrew teacher for recent immigrants during my mandatory army service in Israel during 2006-2008, where I became familiar with the Jewish Ethiopian community. After completing my service, I created music education programs with Ethiopian Israeli students in a Tel Aviv periphery. To this day, I continue to stay in close contact with my students and their families. Upon embarking on this project, I learned that a somber tradition of social science research about the Jewish Ethiopian community made many members hesitant to discuss their Jewish origins, in fear that questions about their religious traditions and practices might lead to deportation. I therefore had to critically reexamine the goals and the norms of the research in which I was to engage. Hence, I conducted this inquiry using Community Based Participatory Research (CBPR) methods from the field of Public Health. My goal was to depolarize the relationship between academia and community by tending to social, structural and environmental inequalities through active involvement of community members, organizational representatives, and researchers in all aspects of the research process (Israel et. al., 1998; Stanton, 2014).

I collaborated with four Ethiopian-Israeli teenage girls between the ages of 15-19, who studied music with me since their childhood. All four were born in Ethiopia and immigrated to Israel as children. In Israel, they live in peripheral neighborhoods, adjacent to Tel Aviv, and were educated in local, public, religious girls-only schools 
or boarding schools. They harnessed their community networks, online platforms and social circles, to establish a trusting relationship with community members to provide us with adequate and multifaceted information for this project. They will be reffered to in pseudonames to comply with IRB guidelines. Our main source of data consists of semi-structured interviews and conversations among community members and Israeli officials, which we all collected over three summers (June-August) 20172019. The recordings, which amounted to 150 hours, inform a larger research project. During summer 2017, I also conducted interviews with Israeli policy makers involved in shaping the policies of absorption of the immigrants from Ethiopia, mainly in the religious track of the educational system. I transcribed all the interviews myself between Winter 2018-2020. In addition, to contextualize our work in the complex historical and current socio-political-religious frameworks, I reviewed and analysed historical and legal documents, and speeches made in the Knesset (the Israeli parliament), letters from Rabbinate officials, and government meeting protocols spanning from the founding years to the present.

In the following, I argue for a tension between three articulations of Jewishness, as a religious tradition, a national identity and a state apparatus. I will build my argument in five major steps. I begin with a brief overview of Judaism, Jewishness and the Jewish people, to set the foundations for discussing the tension above. Second, I turn to the founding of the State of Israel as the national home for the Jewish people, an intensified arena for this tension to be enacted. Then, thirdly, I examine citizenship as a specific case of this tension, and explore how Israel conditioned the citizenship status of Ethiopian Jews on additional Jewish conversion. Subsequently, in the fourth step, I introduce Israel's public educational system as a factory for fabricating national minds, which was divided into mutually-exclusive general and religious tracks. In the fifth, last substantial step, I show how the religious track of Israel's public school system serves to re-educate dark-skinned students, whose identities challenge the dominant perceptions of what being Jewish and Israeli is. I conclude with the unique contribution of Ethiopian Israeli students, whose agency and resilience make this tension visible.

\section{Judaism, Jewishness, Jewish People}

In this first step I explore the complexities of Judaism, Jewishness and the Jewish people, considering elements of unification and division, the Jewish experience of "otherness," and the unique place of the Jewish Ethiopian community as others among the Jewish people.

\section{United}

When Yerus's family set out towards modern Israel to find Yerusalem, they were not necessarily headed in the wrong direction. The Bible describes the Land of Israel as the home of the Jewish people and mourns the exile of descendants across a world-wide diaspora. Whether or not Biblical descriptions of events and people are based in reality, 
they shaped the reality of Jews for millennia. Wherever they were, Jews saw themselves - and were seen by others - as part of one people. In spite of differing circumstances, nationalities, languages, and cultural practices, their peoplehood stemmed from their shared ancestral past - a past they dreamt to revive, somehow, someday (Kaplan, 1934; Herman, 1970; Boyarin, 2003).

Beta Yisrael (House of Israel), the Jewish Ethiopian diaspora, shares this dream of revival. The Beta Yisrael trace themselves back to the exile depicted in the Bible: when the twelve tribes of Israel dispersed across the earth, the Tribe of Dan fled to Egypt. Beta Yisrael claim to be the descendants of the Lost Tribe of Dan, who continued their journey to settle in the areas of Gondar and Tigray, in today's Ethiopia. There, the longing to return to Yerusalem has become the central symbol of their Jewish faith (Ben Ezer, 2002; Ziv, 2017). It was this longing that gave Yerus's mother the power to carry her daughter on her back for 700 kilometres: returning to where her ancestors had come from, and reuniting with her lost kin therein.

\section{Divided}

Although Yerus's family knew where they were heading, they didn't know who or what they might find. Centuries of diaspora made Jews dissimilar from one another. In deep dialogue with practices, values, and norms of their surroundings, being in touch with local cultural tapestries, changed what it meant to be Jewish. Over the millennia, vastly different ways of being Jewish emerged on the spectrum from East and West, and from religious orthodoxy to secularism (Herman, 1970; Charme, 2000; Biale, 2011). Some Jews understood being Jewish as living strictly according to the Rabbinic Halacha, the legal apparatus of Judaism based on the oral and written Jewish traditions and norms rooted in late antiquity, at the time of the Roman Empire (Schiffman, 2003). Other Jews were partially or wholly assimilated, rooted and established in their respective surrounding cultures, to the extent that being Jewish meant very little compared to being German, or Moroccan, or Enlightened. Different communities among the Jewish People seemed to live uniquely different lives.

In that sense, Ethiopian Jews are equally unique among the Jewish People. Their Jewish tradition is based predominantly on the sanctification of the Orit, a portion of the Old testament which consists of the Five Books of Moses with Joshua, Judges and Ruth. Their community structure consists of reverence for elders, proper embodiment of family roles, gender separation, and purity laws regarding food, marriage, menstruation, and burial which shape their everyday lives (Ben Ezer, 1992; Shalom, 2016). The spectrum of Jews in Ethiopia is as wide as everywhere else: from acutely observant Jews who lived in segregated villages, to non-observant Jews who weren't known as such to their neighbours or the authorities (Seeman, 2010).

\section{Otherness: The Jewish Problem}

Across vast divides, Jews shared one thing: being different from others in their surroundings. Their looks, customs, foods, and community practices were triggers for 
ruthless violence and discriminatory regulations in most places. In Ethiopia, the ruling Solomonic Dynasty labelled Beta-Yisrael mockingly "Falasha" (Amharic for "landless wanderer") and forbid them by law to own or inherit land. Beyond discriminatory regulations, they suffered extreme violence for being Jewish: persecution, pogroms, and forced conversions to Christianity (Kaplan, 1995; Hacohen, 2009). In Europe, where the idea of the Jewish State was conceived, the systematic, meticulously designed murder of six million Jews in the Holocaust made Jews into the architype for otherness (Foucault, 1981). While the founding of a Jewish State was discussed as early as the 18th century and gained momentum in late 19th century in the context of radical nationalism in Europe, the Holocaust was central to the actual founding of Israel in 1948. If otherness was the Jewish problem among nations, Jewish national unity was the solution.

\section{Other among Others}

While Beta Yisrael see themselves as part of the Jewish nation, they were not seen as such. They weren't known to European Jews up to the late 19th century, and were not included in the centuries-long correspondence among Jewish communities, which dramatically changed Jewish tradition (Shalom, 2016). Furthermore, as the only East African Jewish diaspora, they were also distinguishable among other Jews by the color of their skin (Ben Eliezer, 2004). They envisioned their unification with the Jewish People "like a drop returning to the sea." But their journey into the State of Israel was not a merging of waters.

\section{Israel: The Jewish state}

In this second section, I examine the State of Israel, from its Zionist roots in European nationalism, through the preliminary development of a state apparatus. Then, I explore the institutionalization of the Rabbinate - a state-founded religious authority - which brought upon the convergence of Jewish law and state law.

\section{Zionism: Jewish Nationalism}

At the end of the 19th century, as the Zionist movement envisioned a Jewish State, it called for a "National Home for the Jewish People" (Balfour, 1917). For the Zionists, Jewish religiosity belonged to the past, and Jewish nationality was the gateway to the future. Like the founder of the Zionist movement, Ze'ev Theodor Herzl, philosopher Hugo Bergman, and activist Sarah Aaronson, most Zionists were not religiously observant, and skeptical about the reality behind Biblical descriptions of ancient Israel. However, being surrounded with powerful articulations of the essential relationship among peoples, land, and culture, they understood being Jewish in those terms (Adler, 1997; Scharfstein, 1997).

The rise of European nation-states in the long nineteenth century (Hobsbawm, 1989) was a turning point for the Jewish People. It illustrated a seemingly undefeatable, 
supporting and stabilizing relationship between a unified nation -- a sanctified, collective entity with essential characteristics, and a state -- apparatuses of political power distribution and participation (Tröhler, 2020). This vision of a nation-state as an ultimately powerful constellation drew Zionists (back) to Palestine: restoring the relationship between Jews as dispersed limbs of a once-unified nation, and allotting them a room or territory of their own over which only they have sovereign state power. But while the vision of a sovereign nation-state deeply enchanted the Zionists, what they had in hand didn't exactly fit into that construct. How can a "state," a sovereign political body, be "Jewish;" and how can Jews, who since antiquity wandered dispersed among nations, form a single nationality?

\section{The Apparatus of the Jewish State}

The establishment of a Jewish State as a nation-state and its legal foundations raised grave questions that necessitated clear-cut definitions. For example, questions about the right to citizenship needed to be answered: What is Jewish? Who is a Jew? However, reality left little room for questions. An off-chance, new state was under constant threat, until the very moment its existence was officiated. During its founding years, a constitution could not be decided upon. The relationship between the people, the dominant Jewish religious tradition (the Rabbinic Halacha), and the state, i.e. the relationship between synagogue and state, was too fragile and volatile to discuss and decide upon during an overwhelming state of emergency (Ona, 1984; Segev, 1984). Meanwhile, Holocaust survivors were placed on the front lines of the 19471949 Palestine war, where many of them died, alongside $1 \%$ of the Jewish population (Morris, 2008). To survive, the young state called to increase its Jewish population, opening its doors to Jews from the various diasporas across the world. Hence, the Law of Return was passed in 1950: A basic entitlement of Jews, it determines that "Every Jew is entitled to make Aliyah (Ben-Guron, et al., 1950)," i.e. immigrate to Israel. But while the Law of Return grants automatic Israeli citizenship to Jews, the term "Jew" wasn't defined in it until 1970. Then, when more and more Jews were eager to make Aliyah, the law was amended, standardizing and regulating who, as a Jew, has the right to citizenship (Corinaldi, 1998).

\section{The Rabbinate}

At this point, the Rabbinate took over. Founded as early as 1921, the Rabbinate is a state-funded, religious institution that plays a central role in determining the boundaries and norms of the Jewish nation-state. Overtime, it gained full control over procedures of Jewish conversion, interpersonal laws, like marriage and divorce, funeral rites, and other rituals with fateful ramifications (Finkelstein, 2014). In 1970, under pressure from the Rabbinate, The Law of Return was amended to include only those Jews who are considered Jewish according to the Rabbinic Halacha, the above mentioned the legal apparatus of Jewish tradition, as defined and lived by Orthodox Jews (Edelman, 
1998; Kravel-Tovi, 2017); vice versa Orthodox Judaism serves a collective term for the traditionalist branches of rabbinic Judaism as the mainstream and thus dominant form of Judaism advocating strict observance of the Halacha. In diasporic settings, the Halacha was supposed to enable dispersed Jewish communities to follow unified and consistent religious practices. However, neither Jewish peoplehood nor Jewish religious practices were ever wholly dependent on or conforming to the rigor of the Halacha. Variations and differences in Jewish norms and practices were the rule rather than the exception. Even within the Halacha, lengthy and often contradictory opinions and views are meticulously collected.

\section{State Law, Jewish Law}

As a state law, the amended Law of Return defines a Jew in the Rabbinic-Halachic tradition as "a person who was born of a Jewish mother or has become converted to Judaism and who is not a member of another religion (Meir \& Shazar, 1970)." Yet, while the Rabbinate determines Jewishness according to the Halacha, its definitions are not transparent to those without Halachic proficiency. Since the Rabbinate has full authority over these conversion procedures, it serves as gatekeeper to both belonging to the quasi-dominant religious community, and citizenship, i.e. membership with full rights in a state.

When the Jewish State embraced Jewish orthodoxy as a formal and fundamental state principle, the coupling of "nation" and "state" turned into a triangle. To this day, Jewish orthodoxy determines Israel's ways: public transportation is forbidden on the Sabbath, marriage and divorce are only legal if performed by Halachic rules, and public restaurants must be supervised and given certificated of being Kosher by the Rabbinate. How those who redefined Jewishness as a national identity end up prescribing and institutionalizing every-day, individual and personal practices as state law is still debated (Elazar, 2006). Meanwhile, this Jewish law hampers the Jewish dream of return for Ethiopian Jews.

\section{Conversion: Condition for citizenship}

Having explored Judaism, Jewishness, the Jewish People, as well as the processes that brought upon the founding of the Jewish state, I laid out the foundations of the tension between three articulations of Jewishness. Now, I turn to explore the conversion policy which conditions the citizenship of Ethiopian Jews, as the first example of this tension. First, I explain the Rabbinate's suspicion about the Jewish ancestry of Ethiopian immigrants; second, I consider the efforts of Ethiopian Jews to fulfil their religious dream of return, and lastly, I show how the Law of Return serves Israel as a gatekeeping practice, which forces Ethiopian Jews to leave their Jewish tradition and their families behind.

When Ethiopian Jews set towards Yerusalem, they aimed to fulfil their Jewish tradition, which they held on to for centuries, as the recorded conversation between 17-year-old Serkalem (pseudoname) and her father shows: 
Serkalem: Why did you choose to make Aliyah (immigrate)?

Father: What's this question?! I'm a Jew. No choice. A Jew belongs in Yerusalem.

(Serkalem\#3, 2017).

Serkalem's father answered her question matter-of-factly: he was born and raised "Falasha," and persecuted all his life for being one. He practices the laws of the Orit which Beta Yisrael sanctifies. He believes that Yerusalem is where his ancestors lived and came from, and as their descendant, he too belongs there. However, instead of religious fulfilment, he witnessed religious sacrifice: Beta Yisrael lost thousands of its community members in their hazardous journeys towards Yerusalem. Now that they arrived at last, they had to leave behind their Jewish tradition to gain entry to the Jewish state.

\section{Suspicions about Jewish Ancestry}

When rumors of a growing Jewish settlement in Palestine reached Ethiopia, Beta Yisrael were eager to join. However, they weren't really invited. In 1942, Rabbi Uziel, the Rabbinate's Chief Rabbi at the time, wrote in a letter: "We cannot see this community as full-Jews according to the Halacha," therefore implying they were not entitled to Israeli citizenship. Confronted with this document, above mentioned Serkalem said: "Every American Jew can get Israeli citizenship in only a couple of hours, while my cousins in Ethiopia have been awaiting Aliyah for over twenty years (Serkalem\#14, 2019).”

The Rabbinate rationalizes this state of affairs through Halachic arguments. As the power lies in its hands, the Rabbinate defines Rabbinic Halacha as criteria for Israel nationality, and implements this definition by the authority of the state. Ethiopian Jewish tradition is based on the earlier, Biblical law, which differs from the rabbinic Halacha to determine what is Jewish and who is a Jew. For example, while the Halacha defines who is a Jew by the birth mother, Biblical law does so by the father. Circumcision of Beta Israel males is conducted by women, in accordance with Biblical customs, while the Halacha only legitimizes circumcision when done by males (Shalom, 2016). Hence, Ethiopian Jews were considered "not Jewish" according to Halachic standards and the Rabbinate withdrew their right for Israeli citizenship according to the Law of Return (Corinaldi, 1998).

\section{Dream to reality}

Beta Yisrael did not wait for recognition. With the Orit in their hands and the dream of Yerusalem in their hearts, they crossed the Sudanese desert like the ancient Israelites, expecting their exodus to lead them to God's Temple that their ancestors left behind. Needless to say, the temple was no longer there when they emerged from the desert, only the Ministry of Aliyah and Integration, which, fortunately, recognized them as historically Jewish in 1973. Rabbi Yosef, Chief Rabbi at that time, declared that Ethiopian Jews are indeed the descendants of the lost Tribe of Dan, basing his conclusion on rabbinic correspondence dated to the 14th century (Corinaldi, 1998). Ever since, over the past forty years, most of the Ethiopian Jewish community arrived in Israel. 
Immigrations occurred in three waves. The first, Operation Moses (1981-1984), was a secretive operation that cost thousands of lives as families walked the Sudanese desert and crossed the Red Sea. In Operation Solomon (1991), an Israeli army task force flew 14,000 Jews to Israel in 36 hours (Ben Ezer, 1992). Israeli officials concluded that no more Jews remained in Ethiopia, yet thousands continued flooding the Israeli embassy in Addis Ababa, spawning Operation Yona (2000-present), by which community members with families already in Israel sporadically fly in (Seeman, 2010).

While an acknowledgement as historically Jewish opened Ethiopian Jews' gateway to Israel, it didn't legitimize their "deviant” Jewish practices. The Rabbinate conditioned their automatic citizenship status on strict conversion according to the Halacha. Since the 1980s Ethiopian Jews had to be converted to Judaism although they were already Jewish, and the males had to be circumcised although they were already circumcised, until community members rebelled against this requirement (Ben Ezer, 2002).

For 16-year old Alamnesh (pseudoname) this makes no sense. Her entire family had to refrain from practicing their traditional Jewish practices, and learn and implement different religious procedures. Why was that necessary for making them into Israeli citizens? Learning about conversion policy in her religious public school didn't provide an answer to her question.

"Today our school Rabbi gathered all the Ethiopians and explained why all-of-asudden the white man comes and tells us to convert. I respect him, but I think that questioning our Jewish tradition is just an excuse. Every rule you bring from the Halacha, there's always a disagreement about it, it's called "Machloket" (Hebrew: disagreement). It's easy to use the Halacha to justify anything, but someone always disagrees. Saying Ethiopians are not Jewish is the easiest thing to do when you don't want them to have citizenship. You don't want Ethiopians in Israel? Find a rule in the Halacha. You do want them? Bring a "Machloket." But you can't say that Ethiopians are not Jewish and that's it, because in the Halacha every question always has two answers (Alamnesh\#11, 2019)."

Alamnesh builds on the Halachic proficiency she gained at religious school to contest the rabbi's logic. As a state law, the halacha goes against its own legacy: if in itself it is composed of conflicting views, how could the Rabbinate univocally determine Alamnesh is not Jewish?! If Jewish conversion is meant only to keep unwanted citizens out, she says, it is not really Jewish.

\section{Law of Return: Losing my religion}

To be accepted as citizens to the Jewish nation(-state), Ethiopian Jews had to leave their own Jewish tradition, cultivated for generations, behind. This grave religious and cultural price was not the only one: the Rabbinate's "clear-cut" definition for who is a Jew in fact cut families apart. Alamnesh's cousins, Serkalem's grandparents, and Workitu's brother are still awaiting Aliyah in Ethiopia, as alternating policies of Israeli governments regarding Operation Yona have put them in limbo for decades. 
As a state policy based on Jewish law, The Law of Return exemplifies the tension between Jewishness as a diverse religious tradition, national identity and a state apparatus. The law refers to Jews as a people, but defines them according to sectorial religious sources that don't represent them all. A state-sponsored institution was given authority to determine citizenship according to these definitions, thus turning the religious act of conversion into a gatekeeping practice, allowing dubious definitions of who is a Jew and perceptions of desirability or non-desirability of potential citizens to delineate the boundaries of the Jewish nation. This conversion policy forced Ethiopian Jews to sacrifice their religious tradition as well as the wholeness of their families and community for Israeli citizenship. Serkalem's sense that this process is not "Jewish" is not mistaken: Israel's definition of a Jewish person as someone with a Jewish mother is reminiscent of the Nuremberg race laws that made the Holocaust possible.

\section{Public Jewish education: Building a nation between state and religion}

In research it is taken for granted that schools are instruments in the fabrication of future citizens with national minds as a cornerstone of national identity. This fourth section will demonstrate that this also holds true for Israel, focusing on the religious track of the public-school system.

In the founding years of the state, heated discussions about the national character filled the rooms of the young parliament. "Israelis" never existed before, and multiple ideological streams wanted to determine what they would be like. Their battle over public education, the "factory" for constructing the loyal, culturally-coveted, nationally-oriented citizens (Tröhler, 2020), was intensely charged. Similarily to other nation-building projects in liminal territories, such as Alsace and Lorraine (Harp, 1999) or on the US-Canadian border, the state was given a central role in "fabricating" loyal national minds through schooling (Tröhler, 2020). In 1953, Ben Zion Dinur, Israel's first minister of education, thought the only solution would be to unify the ideological streams under a single umbrella of state-run public education (as cited in Marom, 2005, p. 305):

"For two thousand years, we [Jews] weren't responsible for state and government. Now we gather here - expats of different nations, sons of foreign cultures, different educations and conflicting views; nonetheless, we want to build a home for all of us [...]. From former Algerians, Moroccans and other Easterners we must now build a People. The State is the greatest, most efficient tool for the construction of the People."

Dinur's attempt to centralize public education was institutionalized the Law of Unification. The mission of Israeli public education was "building a People" out of geographically and ideologically dispersed populations. Dinur emphasized the power and the centered significance of the state with institutions serving as mechanism for unifying Israelis, seculars and observants, whether from the East or from the West. In 
practice, however, public education got divided quite literally between these distinct four groups among Israelis. The Rabbinate demanded that children from religious families attend an independent educational system, segregated by gender, with emphasis on a religious curriculum. With the support of political parties whose members where mainly Jewish orthodox, the state-sponsored educational system was split into two tracks: the (general, default) state-run public education system (Mamlachti), and the religious (Jewish orthodox) public education system (Mamlachti-Dati, referred to herein as MD), where children of Ethiopian decent ended up. Together, these systems cater to the majority of Israel's students, but not to its extreme outskirts: children of ultraorthodox Jewish families, and children of Israeli Arabs, who lead semi-independent yeshivas and sectorial schools, respectively.

\section{Public religious education}

The MD system is described in its official website as a "Public education system whose institutions, lifestyle, curriculum, teachers and supervisors, are religiously Jewish." Its mission is as follows: "Educating for a life of Torah and Mitzvot according to the orthodox Jewish tradition and in the spirit of religious Zionism," (State of Israel Ministry of Education, n.d.). This interweaving of national and religious normativity is supported in state structure: The Law of Unification granted special privileges to the religious public education system: an orthodox rabbi as a supervisor, a consulting committee of rabbis that guides the ministry of education in policy making. Furthermore, the MD has its own independent curriculum and emphasizes the study of Jewish texts, history, and normative lifestyle. The teaching of general education topics, such as history, English and science, is adjusted according to the system's religious values. In 2018, the MD served $17 \%$ of Israeli students. While the system educates for a Jewishly-observant life, $25 \%$ of its students are not observant. Most of their families are of low or very low socioeconomic status, and 25\% live in peripheral "development towns" (Finkelstein, 2012; Ravnizki, 2005; yearly government report on public religious education, 2012).

\section{Education and re-education}

In this fifth and final section, the second example of the aforementioned tension is explored: state-mandated schooling of Ethiopian Jews in the religious track of the public-school system. First, I recount how the majority of Jews of African and Middle-Eastern origin were channelled into the religious track of the Israeli publicschool system. Second, I look at the framing of re-education as a "compromise" for the national inclusion of Ethiopian Jews. Third, I show how this trajectory created a reality of difference and school-failure which dismantled students' identities.

The reasons behind the demographics above originate from the absorption of the great North-African Jewish diaspora during the early 1950s. In only two years, Israeli society had doubled, and while the European founders were eager to increase Jewish 
population, they were terrified of losing the battle over the national character to the Mizrachi (Middle-Eastern and North-African) newcomers, who were now equal to them in numbers. As cited in Marom (2005), reshaping the younger generation of "Moroccans" and "Algerians" into the desired cultural image was a key strategy for making them into one people, one nation. Hence, the distinction between education and re-education in Israeli public schools became even weaker. Children of North-African decent were to be brought closer to the secular national ideal that the Eurocentric founders had in mind. When the general education system was not as successful as they hoped, children of North-African decent were redirected to the MD. Currently, students of North-African decent form $90 \%$ of MD student population (Central Bureau of Statistics, 2019).

\section{Re-education as compromise}

In 1984, the rabbinic supervision committee ordered the MD to take-on all Ethiopian immigrants as an inseparable part of their conversion. The late head of MD at the time of absorption, Shimon Adler, told me in an interview, "They said, 'We're Jewish,' the Rabbinate said, 'We don't know what they are,' religious education was the compromise, (Adler\#1, 2017)."

At first, the MD didn't want to be that compromise. The national identity that this system educated for was both Jewish orthodox and "in the spirit of Zionism," after all a Eurocentric model of Jewish nationality which shaped Israel's vision of the Jewish collective as a whole. Adler was concerned about the distance between these Jews and that national model: "We had to build a bridge over 2000 years of Jewish development," Adler said, referencing the difference between the Ethiopian Jewish tradition and the Halacha, "It is more challenging with them than with any other Jewish community that ever arrived in Israel, (Adler\#1, 2017)."

Thus, a singular trajectory was developed at the MD for children of Ethiopian decent. The system's polarized structure seemingly made way for children of Ethiopian decent to be "included," but in reality kept them apart. In the 1980s, $95 \%$ of Ethiopian children were sent to boarding schools (Finkelstein, 2012; Ben Ezer, 2002). In the 1990 and 2000s, they were defined as "at risk," separated from their classmates and placed in designated absorption classes, separate tracks, and special education tracks that would better support their cultural transition (Berhanu, 2005). Today, 44\% of Ethiopian-Israelis attend this system, but graduate high school in significantly smaller percentages than the overall student public (Central Bureau of Statistics, 2019).

\section{From special to different}

This separation was so hard on 17-year old Alamnesh, that she decided to switch schools. In her previous MD school, with a few exceptions, all the girls were of Ethiopian decent, in this one, she's "the only Ethiopian in class." What it means for Alamnesh to be in a minority was surprising for me: 
The farangi girls in my class think I pity myself, but every second in that school I'm proud to be Ethiopian. First, I have the perfect color. Second, I have my own tradition, strong roots and a very special and unified community. My teacher tells us, "What are the chances of being born a Jew?! 1\% of the entire world!" So just think what are the chances of being born an Ethiopian Jew! (Alamnesh\#9, 2018)

With "strong roots" and "special unified community," Alamnesh sees her minority status in Israel by the same logic diasporic Jews understood their scarcity elsewhere: extraordinary uniqueness. The 151,000 Ethiopian Jews living in Israel are indeed scarce, they constitute less than $2 \%$ of Israeli society (Central Bureau of Statistics, 2019). 19-year old Workitu (pseudoname) remembers the first time she realized she wasn't just special:

I was 10 when I got my first A+ in math, and I was the only one in the class. The teacher got angry: "How come SHE got it right and you Israelis didn't?!" I was so surprised. I was sure I was Israeli. (Workitu\#3, 2017)

Workitu is puzzled: everyone immigrated to Israel from somewhere, why is she different? Can't she become Israeli too? More than other minority groups in Israel, Ethiopian Jews are distinguishable. While no official state policy explicitly addresses their darker complexion, Ethiopian-Israelis are socially categorized as different for their skin color (Berhanu, 2005; Ben Eliezer, 2004).

Alamnesh doesn't feel her skin makes her different. Color-jokes are part of her school routine, as her friends are Moroccan, Russian, Tunisian. Her best friend, Naama, is of Yemenite origin, and they always joke during breaks. "What is the difference between a Yemenite and an Ethiopian?" Alamnesh asks and Naama answers, "A few minutes in the oven (Alamnesh\#2, 2017)!" Alamnesh observes an ethnic spectrum around her, and she doesn't consider her spot therein to be the source of her difference: "You would know I'm Ethiopian even if I was white, (Alamnesh\#2, 2017)" she said. Being Ethiopian is indeed different from being Israeli: one must honour elders and never talk back to them, often kneel to kiss their knees; one must account seven generations back to get married within the community, and observe slightly different holidays. These variations on Jewish practice were part of the reason school requires children of Ethiopian decent to teach their parents "correct" Judaism upon returning home (Ben Ezer, 1992; Berhanu, 2005). Workitu (19) remembers how much she hated these classes:

I used to ditch these classes all the time. Couldn't stand them. Especially when they said not to eat my mother's food because it's not Kosher. Who do they think they are?! I stopped going and dropped out. (Workitu\#8, 2018)

\section{From difference to failure}

Having to teach what she learned at school to her parents, and to refuse to eat her mother's food was impossible for Workitu, whose Jewish tradition emphasizes respect for elders. But school teaches Ethiopian children to suspect their parents rather than 
respect them, thus dismantling core values of their Jewish tradition. Workitu felt this left her no choice but to fail at school. When I told this to the school counselor, she got furious:

No other community received resources like this one. So many enrichment classes, afterschool tutoring. All to the garbage! We beg the girls to attend but they don't show up, and these classes are coloured black so no one else can join. We ask of the Ethiopians almost everything we demand from Israelis, but we know that they have an identity confusion so we try not to push too hard. (School-counselor\#1,2017)

Workitu's school received donations that were "colored black," specified for EthiopianIsraeli students, who chose not to attend the activities they fund. Trying "not to push too hard," the counselor creates unpassable divides between "Ethiopians" and "Israelis:" referring to "Colored Black" budgets, although Ethiopian students don't identify thus, and even "softening" school policies due to their "Identity Confusion." But that Workitu might be confused by the fact that her school counselor distinguishes between "Ethiopians" and "Israelis" doesn't even cross her mind. It attests, however, to the MD thesis about the desired national model where some can simply be "Israeli" while others have to stick around for Jewish Enrichment afternoon classes to catch up.

For many like Workitu, the "Bridge over 2000 years of Jewish development" was a downward facing slide towards school failure and consecutive socioeconomic marginalization. Pnina Tamano Shata, an Ethiopian-Israeli parliament member who attended MD schools as a teenager, spoke about the experience in the Israeli parliament (Diveri HaKnesset, 2018):

W've come to be the punchbag of many, many educators, that in the darkness of their minds think they can hurt the personal, physical safety or wellbeing of kids of Ethiopian decent, without getting fired. No one withholds state funds from schools that don't accept Ethiopian children - and there are many. Ethiopian children are separated in classes, kindergartens, and schools. Separation is the best-case scenario, the worse is blunt child abuse that no one is asked to explain.

\section{Dismantle to belong}

Tamanu-Shato painfully illustrates the exclusive and discriminatory reality of Ethiopian Jews in MD schools, which contributed immensely to the growing enmity between Ethiopian-Israelis and the police. $14 \%$ of minors of Ethiopian decent have been charged with law offences and they experience police brutality more than any other Jewish community in Israel (Mizrachi \& Herzog, 2012). During summer 2019, the above-mentioned shooting of 18-year-old Solomon Takkah by an off-duty policeman got ten-thousand Ethiopian-Israelis protesting in the streets. The demonstrations enhanced the divide between "Ethiopians" and other Israelis. Online harassments, being stared at on the bus and feeling unsafe in the presence of cops became daily occurrences for Alamnesh: 
Many of my friends are farangi and I never felt different from them. But this year the murder and the demonstrations made me stop and think. Maybe racism does exist and I just don't want to let myself see it? If God forbid a cop shoots my little brother, what will my farangi friends do? Sit in front of the TV and say, "Awe this is so sad." Farangis have no idea where I live. The state I live in and the state they live in is not the same state. (Alamnesh\#16,2019)

In summer 2019, the difference between Naama and Alamnesh was no longer "a few minutes in the oven." By then, it was a different state. Skin complexion is not enough to explain the barrier between Ethiopian Jews and Israeli society. As Jews have an array of skin complexions, the difference between Yemenite and Ethiopian Jews is no greater than, say, Ukrainian and Spanish Jews. Why in this case, is a difference in skin complexion also a difference in citizenship status, educational opportunity, and personal safety?

\section{Jewish State exclusive of Jews}

Albeit its promise as the "National Home for the Jewish People," the Jewish State was soon enough exclusive towards Jews, especially those of African origin. The MD system treats Jewish religiosity, nationality and statehood as mutually inclusive, but its Eurocentric approach to Jewish nationality, alongside the orthodox approach to Jewish religiosity, ultimately excludes students of Ethiopian decent and sets them up for failure under the guise of inclusion, while tearing apart their family and community structures. As a state-mandated educational system for students of Ethiopian decent, this pedagogy paves the path to their marginalization, school-failure and incarceration. Distinguishing between national and state power is important for realizing the workings of the MD, which champions a dominant vision of the desired national citizen using its state power. How the state mandated MD schools re-educate Jews of African origin became a central mechanism of social stratification in Israel's first decades. By the time Ethiopian Jews arrived, Jewish orthodoxy established its own education systems, which knew how to make "the wrong-kind" Jews into "right-kind" ones.

\section{Conclusion}

Yerus's journey to Yerusalem started on her mother's back, and ended in a "different state:" the State of Israel. She witnessed as Yerusalem turned from a religious symbol, into a peoplehood to which she longed to belong, and finally into a state apparatus that blocked her path with a sign that says "Black = second class citizen."

Two processes initiated and supported by the state served to dismantle Ethiopian Jews' religious and national Jewish identity: conversion and mandatory education at the MD religious public-school system. Both processes involve Jewish religion, but are imposed and enforced in state structures. How Ethiopian Jews had to lose their religion, to belong to the Jewish State, exemplifies the tense relationship between Jewish religiosity, Jewish nationality and Jewish statecraft. These are not a continuum, 
but rather an unresolved tension. The fact that all three entities build on Jewish vocabulary, scripture and history, make this tension potentially invisible. If anything, the darker skin tone of Ethiopian-Israelis helps to recognize and realize it is there.

The "identity confusion" Alamnesh's school counselor attributed to EthiopianIsraelis is not at all theirs. It is her own: a national identity confusion which results from a false equivalence between these three articulations of Jewishness, when the tension among them is essential and consequential. Ethiopian-Israelis are Israel's best chance for gaining clarity, because they manage this tension in their everyday lives. Their religious devotion to Yerusalem didn't make Israel think of them as Jewish, and doesn't make Israelis think of them as Israeli. Nonetheless, Alamnesh questions skin complexion as basis for difference in citizenship status. Serkalem questions the Rabbinate's Jewish ways when it determines she's not Jewish. Workitu questions her school's degrading policy towards her parents. As they continue to inquire and grow against the grain, they will find answers and create surprising solutions. Looking into this complex religious-socio-political phenomenon from their personal perspective illuminates their agency and resilience, and shows, beyond doubt, how important the Jewish Ethiopian community is for Israel to grow in a healthier direction. It might be another exodus, but at least, Yerus can guide us through it:

"Life in Israel is like a second exodus. If my first exodus was about who I am, where do I come from and how do I fulfil my dream, in my second exodus I lose myself, my identity: who will I become? What will be next?" (Yerus\#7, 2018)

In many ways, Yerus's words are much more clear than any scholarly interpretation can illunimate. Her journey to Yerusalem was motivated by religious desire, following the footsteps of the ancient Israelites, to fulfil the Jewish dream of return. But while the desert she crossed may have been the same desert, the way Ethiopian Jews have to sacrifice their Jewish tradition to gain entry to Israel, dismantle their identities to be authoritatively redefined as Blacks, and eventually become members on the lower social end of the Jewish nation-state, attests to an unpassable divide between those Israelites and modern Israel. As a nation-state whose policies and institutions are bounded by Jewish law, Israel marries ideas of Jewish unity and return with European notions of nationality. Inevitably, this brings about a Jewish State exclusive and discriminative of dark-skinned Jews, and weakens its promise as the national home for the Jewish People.

\section{References}

\section{Sources}

\section{Interviews}

Adler\#1: Interview held on 30.08.2017, transcribed on 05.02.2018.

Alamnesh\#9: Interview held on 23.08.2018, transcribed on 10.01.2019.

Alamnesh\#11: Interview held on 20.06.2019, transcribed on 02.01.2020.

Alamnesh\#16: Interview held on 15.08.2019, transcribed on 20.01.2020. 
School-Counselor\#1: Interview held on 22.08.2017, transcribed on 12.01.2018.

Serkalem\#3: Interview held on 20.07.2017, transcribed on 05.01.2018.

Serkalem\#14: Interview held on 31.07.2019, transcribed on 03.02.2020.

Workitu\#3: Interview held on 14.08.2017, transcribed on 15.02.2018.

Workitu\#8: Interview held on 03.08.2018, transcribed on 08.01.2019.

Yerus\#7: Interview held on 28.06.2018, transcribed on 06.02.2020.

Yerus\#18: Interview held on 17.08.19, transcribed on 14.01.2020.

\section{Documents}

Balfour, A. (1917). The Balfour Declaration [Public statement.] https://www.jewishvirtuallibrary. org/text-of-the-balfour-declaration

Ben-Gurion, D., Shapira, M., Sprinzak, Y. (1950). Israel: Law No. 5710-1950, The Law of Return. https://www.jewishvirtuallibrary.org/israel-s-law-of-return

Central Bureau of Statistics. (2019). The Ethiopian Population in Israel (Report No. 355) [Data Report]. https://www.cbs.gov.il/he/mediarelease/DocLib/2019/355/11 19 355b.pdf

Diveri HaKnesset. (2018). Enhancing the integration of Israelis of Ethiopian Descent Essential Flaws in the Management of the National Program. State Controller's Report, 4, 741-743. https://www.mevaker.gov.il/(X(1)S(ibmyag45lg0gapc422m0duai))/sites/ DigitalLibrary/Pages/Reports/244-1

Knesset Center for Research and Information. (2012). Data on Mamlachti-Dati education. https:// fs.knesset.gov.il/globaldocs/MMM/15556b58-e9f7-e411-80c8-00155d010977/2 15556b58e9f7-e411-80c8-00155d010977 11 6959.pdf

Meir, G., \& Shazar, S. (1970). Israel: Amd. No. 2 5730-1970, The Law of Return. https://www. jewishvirtuallibrary.org/israel-s-law-of-return

State of Israel Ministry of Education. (n.d.). Religious Education Administration. https://edu. gov.il/sites/Hemed/Pages/homepage.aspx

\section{References}

Adler, J. (1997). Restoring the Jews to Their Homeland: Nineteen Centuries in the Quest for Zion.J. Aronson.

Ben Ezer, G. (1992). Like Light in a Pitcher: Immigration and Absorption of Ethiopian Jews in Israel. Reuven Mas Press.

Ben Ezer, G. (2002). The Ethiopian Jewish Exudos: Narratives of the Migration Journey to Israel 1977-1985. Routledge.

Ben-Eliezer, U. (2004). Becoming a Black Jew: Cultural Racism and Anti-Racism in Contemporary Israel. Social Identities, 10(2), 245-266. https://doi.org/10.1080/1350463042000227371

Benny, M. (2008). 1948: A History of the First Arab-Israeli War. Yale University Press.

Berhanu, G. (2005). Normality, Deviance, Identity, Cultural Tracking and School Achievement: The Case of Ethiopian Jews in Israel. Scandinavian Journal of Educational Research, 49(1), 51-82. https://doi.org/10.1080/0031383042000302137

Biale, D. (2011). Not in the Heavens: The Tradition of Jewish Secular Thought. Princeton University Press. https://doi.org/10.1515/9781400836642 
Boyarin, D., \& Boyarin, J. (1993). Diaspora: Generation and the Ground of Jewish Identity. Critical Inquiry, 19(4), 693-725. https://doi.org/10.1086/448694

Charme, S. (2000). Varieties of Authenticity in Contemporary Jewish Identity. Jewish Social Studies. 6, 133-155. https://doi.org/10.2979/JSS.2000.6.2.133

Corinaldi, M. (1998). Jewish Identity: The Case of Ethiopian Jewry. Magness Press.

Edelman, M. (1998). Who is an Israeli?: "Halakah" and Citizenship in the Jewish State. Jewish Political Studies Review, 10(3,4), 87-115.

Finkelstein, A. (2012). Religious public education in Israel: status report, tendencies and achievements. Kibbutz Be'erot Yitzkhak: Ne'emanei Torah ve Avodah. (Original in Hebrew).

Finkelstein, A. (2014). The Ethnic Duality in the Rabbinate's Roles in Israel [Report].The Institution for Zionist Strategy.

Foucault, M. (1981). The History of Sexuality Volume 1. Penguin (trans. R. Hurley).

Hacohen, R. (2009). The Kabrä Nägäst (Glory of the Kings): The National Ethiopian Epos. Yad Ben Zvi.

Harp, S. (1999). Learning to Be Loyal, Primary Schooling as Nation Building in Alsace and Lorraine (1850-1940). Northern Illinois University Press

Herman, S. (1970). Israelis and Jews: The Continuity of an Identity. Random House Inc.

Hobsbawm, E. J. (1989). The Age of Empire: 1875-1914. Vintage Books.

Israel, B.A, Schulz, A.J, Parker, E.A,. \& Becker, A.B. (1998). Review of Community-Based Research: Assessing Partnership Approaches to Improve Public Health. Annual Review of Public Health, 19, 173-202. https://doi.org/10.1146/annurev.publhealth.19.1.173

Jewish Daily News. (2020). First publication: The letter of the late Chief Rabbi, which contradicts the rabbinical ruling, was revealed. https://www.jdn.co.il/breakingnews/1274731/

Kaplan, S. (1995). The Beta Israel (Falasha) in Ethiopia: From Earliest Times to the Twentieth Century. New York University Press.

Kravel-Tovi, M. (2017). When the State Winks: The Performance of Jewish Conversion in Israel. Columbia University Press. https://doi.org/10.7312/krav18324

Lawrence, S. (2003). Understanding Second Temple and Rabbinic Judaism. KTAV Publishing House.

Marom, D. (2005). Constitution, Marriage and Education: Interrelations between Religion and State in the Thought of Ben Zion Dinur. In A. Ravtizki (ed.), Religion and state in twentieth-century Jewish thought (pp. 295-357). The Israel Democracy Institute.

Mizrachi, N., \& Herzog, H. (2012) Participatory Destigmatization Strategies among Palestinian Citizens, Ethiopian Jews and Mizrahi Jews in Israel. Ethnic and Racial Studies, 35(3), 418 435. https://doi.org/10.1080/01419870.2011.589530

Ona, M. (1984). In Separate ways: the Religious Parties in Israel at the Founding of the State and in the First and Second Knesset. Yad Ben Zvi. (Original in Hebrew).

Scharfstein, S. (1997). Chronicle of Jewish History: From the Patriarchs to the 21st Century. Ktav Publishing House

Seeman, D. (2010). One People, One Blood: Ethiopian-Israelis and the Return to Judaism. Rutgers University Press.

Segev, T. (1986). 1949: The First Israelis. Henry Holt \& Company. 
Shalom, S. (2016). From Sini to Ethiopia: The Halachic and Conceptual World of Ethiopian Jewry. Gefen Publishing House.

Tröhler, D. (2020). National Literacies, or Modern Education and the Art of Fabricating National Minds. Journal of Curriculum Studies (pp. 1-17). https://doi.org/10.1080/0022 $\underline{0272.2020 .1786727}$

Ziv, Y. (2017). The Holidays of Beta Yisrael. Mofet Institute.

\section{Marva Shalev Marom}

Concentration in Education and Jewish Studies

Graduate School of Education

Stanford University

487 Lausen Mall, Stanford, CA 94305

marvashm@stanford.edu 


\section{Drugi egzodus: etiopski Židovi u Izraelu između religije, nacije i države}

\section{Sažetak}

Pitanja židovstva, judaizma i Židova teme su povijesnih, milenijski dugih debata. U ovom radu fokusiram se na formiranje socijalnih, na boji kože zasnovanih hijerarhija u Izraelu, kako bih dokazala da postoji neriješena, a ipak posljedična napetost između definicija židovstva kao religijske tradicije, nacionalnoga identiteta i državnoga aparata. Objeručke prihvaćam perspektivu etiopskih Židova čiji su identiteti kao crnaca ponovo oblikovani u Izraelu, da ilustriram kako je spomenuta napetost smjestila tamnopute imigrante izvan dosega oboje židovske religijske tradicije i nacionalnoga identiteta, stavljajući ih u poziciju marginaliziranih stanovnika židovske države. Stoga opisujem i ispitujem dva državno nametnuta procesa u kojima izraelski rabinat igra središnju ulogu: 1) izraelski zahtjev za preobraćanjem etiopskih Židova na judaizam kako bi im se dodijelilo državljanstvo; 2) izraelski zahtjev da djeca etiopskih Židova pohađaju segregacijsku školu za ortodoksne Židove kako bi stekli i kultivirali poseban nacionalni identitet. Državne škole postale su osnova za obrazovanje obojega: nacionalnoga i religijskoga identiteta te preodgoj.

Ključne riječi: boja kože; cionizam; imigracija; religijski preodgoj; židovski nacionalizam. 